\title{
First Report of Human Gastroenteritis Caused by Escherichia Coli O157: $\mathrm{H}^{-}$
}

\author{
Santos RFC ${ }^{1}$, Nascimento J DS ${ }^{2}$, Geimba MP, \\ Hessel CT $^{4}$ and Tondo EC ${ }^{4 *}$ \\ ${ }^{1}$ Superintendency of Sanitary Surveillance, Inspection \\ and Nutrition in Food of the City Hall of the City of Rio de \\ Janeiro, (SMS/ SUBVISA/SVFSAN), Brazil \\ ${ }^{2}$ Laboratory of Microbiology, Federal Institute of \\ Education, Science and Technology-Rio deJ aneiro \\ Campus, Brazil \\ ${ }^{3}$ Institute of Basic Health Sciences, Federal University of \\ Rio Grande do Sul (UFRGS), Brazil \\ ${ }^{4}$ Institute of Food Science and Technology, Federal \\ University of Rio Grande do Sul (ICTA/UFRGS), Brazil \\ *Correspondling author: Eduardo Cesar Tondo, \\ Instituto de Ciência e Tecnologia de Alimentos, \\ Universidade Federal do Rio Grande do Sul (ICTA/ \\ UFRGS), Porto Alegre, RS, Brazil
}

Received: November 08, 2016; Accepted: January 16, 2017; Published: January 20, 2017

\section{Introduction}

Escherichia coli are a broad group of bacteria including harmless commensals up to highly pathogenic strains [1]. Among them, Enterohaemorrhagic Escherichia coli (EHEC) constitute a subset of serotypes of Shiga-Toxin (Stx)-Producing E. coli (STEC) firmly associated with severe human illnesses like bloody diarrhea and Hemolytic Uremic Syndrome (HUS). STEC/EHEC strains have been isolated from several foods, including an increasing number of unusual food vehicles associated with human infections [2-5]. Currently, the most common STEC associated with human diseases is E. coli $\mathrm{O} 157: \mathrm{H7}$ [6] and the identification of the $\mathrm{H} 7$ flagellar antigen is critical for the confirmation of this strain, however, some clinical isolates of E. coli $\mathrm{O} 157$ are Nonmotile (NM) and do not produce detectable $\mathrm{H}$ antigen [7], being designated E. coli O157:NM or E. coli $\mathrm{O} 157: \mathrm{H}^{-}$.

E. coli $\mathrm{O} 157: \mathrm{H}^{-}$was first recognized as food pathogen in 1988 , during an HUS outbreak, in Bavaria, Germany [8]. The strain involved with this outbreak had stx2 gene, responsible for the expression of Shiga-toxin, was non-motile and was able to ferment sorbitol. The finding of this uncommon O157 strain causing HUS in humans motivated in-deep studies. For example, in Germany, during the period between 1988 and 1991 [9], calculated the percentage of cases of E. coli O157: $\mathrm{H}^{-}$responsible for diarrhea and HUS and have shown 7.4 to $25 \%$ and 13.3 to $40.5 \%$ of the cases of these two syndromes were caused by E. coli $\mathrm{O} 157: \mathrm{H}^{-}$, respectively. Also in Bavaria, during the winter of 1995/1996, one big outbreak was caused by E. coli O157: $\mathrm{H}^{-}$, resulting in 28 children-cases of HUS and 3 fatal victims [10]. The mechanisms of pathogenicity of E. coli $\mathrm{O} 157: \mathrm{H}^{-}$are not completely understood and some hypotheses raised. For example, in Austria [8], suggested that Shiga-toxin production was not essential for pathogenicity of E. coli O157 in humans. Similarly, in Germany [11], have reported that serotypes $\mathrm{H} 7$ and $\mathrm{H}^{-}$may be involved in foodborne outbreaks even without a uniform production of Shiga-toxin. Other study reported that some strains of $E$. coli $\mathrm{O} 157: \mathrm{H}^{-}$may lost stx genes during infections, isolation and cultures and others strains of E. coli $\mathrm{O} 157: \mathrm{H}^{-}$that are Shiga-toxin positive evolved from nonShiga-toxin producing E. coli $\mathrm{O} 157: \mathrm{H}^{-}$strains, acquiring stx genes from bacteriophages [9]. Shiga-toxin production generally occurs due to the induction of stx genes after stress conditions, mainly oxidative stress [12]. Karch and Bielaszewska [9] have suggested that E. coli $\mathrm{O} 157: \mathrm{H}^{-}$is frequent involved in foodborne outbreaks during cold periods of the year, mainly involving children $<3$ years-old. Bielazewska [13] also demonstrated that E. coli $\mathrm{O} 157: \mathrm{H}^{-}$was isolated from dairy cattle, indicating that these king of animals can be natural reservoirs, just as they are for E. coli O157:H7. Nielsen, et al. [14] reported that sorbitol fermenting and Shiga-toxin producing E. coli $\mathrm{O} 157: \mathrm{H}^{-}$are rare but emergent in Europe and syndromes produced by these strains frequently result in HUS. Brandal et al. [15] have reported that E. coli $\mathrm{O} 157: \mathrm{H}^{-}$cases were frequent in Europe, but its reservoir and exposure routes remained unknown. Sallam et al. [16] demonstrated that sorbitol fermenter E. coli $\mathrm{O} 157: \mathrm{H}^{-}$emerged as an important foodborne pathogen in Africa and this microorganism has been responsible for HUS cases, even with higher rates than nonfermenting sorbitol E. coli O157:H7.

In Brazil, E. coli O157:H7 has been rarely isolated, however few studies demonstrated its presence in bovine feces $[17,18]$ and recently, in ground meat [19] and on bovine carcasses [20]. Additionally, there were only two registered gastroenteritis cases attributed to $E$. coli O157:H7 after the consumption of rare red meat, in 2001, in Campinas/SP [21], but there is no register of human gastroenteritis involving E. coli $\mathrm{O} 157: \mathrm{H}^{-}$. The aim of this study was to describe the first case of human foodborne disease caused by E. coli $\mathrm{O} 157: \mathrm{H}^{-}$in Brazil. 


\section{Materials and Methods}

\section{Outbreak investigation}

The foodborne outbreak was investigated by the Sanitary Surveillance Service of the municipality of Rio de Janeiro, Brazil, following recommendations of Pan-American Health Organization/ World Health Organization [22]. Sanitary Surveillance Service of the State of Minas Gerais helped Sanitary Surveillance Service of Rio de Janeiro in epidemiological investigation, because the victim and involved people had travelled to Minas Gerais some days before the burden of symptoms.

\section{Notification and general investigation procedures}

The outbreak notification occurred by telephone (September 13, 2005) informing a case of severe diarrhea to the Technical Center of Sanitary Surveillance Service of Rio de Janeiro (RJ), starting routine foodborne investigation. Officers were mobilized to carry out in-depth investigation with the victim and involved persons and to collect stool and food samples, if possible. Case patient and controls were interviewed personally or by telephone using routine questionnaire for foodborne outbreaks investigation. Hypothesisgenerating questions were done in order to identify commonly consumed foods and places of consumption. Suspect establishments were visited in Rio de Janeiro and Minas Gerais in order to verify Good Hygiene Practices (GHP), Standard Operating Procedures (SOP) and adherence to the Brazilian food safety regulation. Food handlers were interviewed regarding food preparation and recent illnesses. Stools and suspect food samples were collected and sent to the Reference Laboratory of Public Health of Rio de Janeiro, Noel Nutels in order to be analyzed following methods described by FDA/ CFSAN [23]. The identification of bacterial isolates was carried out in Fundacao Osvaldo Cruz, Rio de Janeiro as follow:

\section{Microbiological testing}

Stool samples ( $10 \mathrm{~g}$ ) were homogenized in $90 \mathrm{ml}$ peptone water diluent. After that, serial tenfold dilution was prepared using the same diluents, according to the expected level of contamination. $0.1 \mathrm{ml}$ of each dilution in duplicate was spread onto dried surface of sorbitol-MacConkey (SMAC) agar (Oxoid, England). The plates were incubated at $35^{\circ} \mathrm{C}$ and read after $18 \mathrm{~h}$. Food samples $(25 \mathrm{~g})$ were homogenized in $225 \mathrm{ml}$ of modified Trypticase Soy Broth (mTSB, Oxoid, England) containing $0.45 \mathrm{mg}$ of novobiocin (Laborclin, Brazil) and incubated at $37^{\circ} \mathrm{C}$ for $24 \mathrm{~h}$. After incubation, $0.1 \mathrm{ml}$ of enrichment broth were spread onto Tellurite-Cefixime-Sorbitol MacConkey Agar (TC SMAC, Potassium tellurite $2.50 \mathrm{mg} /$ liter and Cefixime $0.05 \mathrm{mg} /$ liter) and incubated at $37^{\circ} \mathrm{C}$ for $24 \mathrm{~h}$. Sorbitolnegative colonies (pale colonies) were picked from TC SMAC and characterized by biochemical tests (indole and beta-glucuronidase assay). Motility was carried out successively growing suspect isolates in semisolid agar (concentrations of $0.2 \%$ to $0.8 \%$ ) according to Ewing [24]. Non-motile, indole-positive and beta-glucuronidase-negative isolates were tested for agglutination with E. coli $\mathrm{O} 157$ antiserum in the Reference Laboratory of Enterobacteriaceae in Fundacao Osvaldo Cruz-FIOCRUZ, following methods of FDA/CFSAN [21] and Orskov and Orskov [25]. O157-positive isolates were further analyzed by tissue culture assay for verotoxins (Shiga-like toxins) [23] as described below. Non-O157 STEC isolates were not investigated.

\section{Tissue culture assay for verotoxins}

Bacterial culture preparation: E. coli $\mathrm{O} 157$ isolates were inoculated in $20 \mathrm{ml}$ Trypticase Soy Broth (TSB) and incubated at $37^{\circ} \mathrm{C}$ for $20-24 \mathrm{~h}$. Bacterial cultures were centrifuged at $7000 \mathrm{xg}$ for $30 \mathrm{~min}$ and the supernatant was filtered through $0.45 \mu \mathrm{m}$ membrane in order to remove residual cells. The filtrate was stored at $4^{\circ} \mathrm{C}$ and before use, was 1:5 diluted in Dulbecco's phosphate-buffered saline (DPBS), $\mathrm{pH} 7.0$

Preparation of vero monolayer's: Vero culture was maintained in Eagle's minimal essential medium (MEME-L15) containing 2\% milk serum added of gentamicin sulfate $(50 \mu \mathrm{g} / \mathrm{ml})$. Before use, the purity of culture was checked in $5 \% \mathrm{CO}_{2}$ incubator held at $36^{\circ} \mathrm{C}$ for $72 \mathrm{~h}$. Normal cells were treated with trypsin to remove monolayer. Cells were suspended to the density of $10^{5}$ per $\mathrm{ml}$ in growth medium and portions of $0.5 \mathrm{ml}$ were transferred to $16 \mathrm{~mm}$ wells in sterile plastic dishes. Cells were incubated for $3-4$ days at $36^{\circ} \mathrm{C}$ in $\mathrm{CO}_{2}$ incubator. Growth medium was removed and replaced with $0.5 \mathrm{ml}$ fresh medium.

\section{Toxicity test}

Portions of $0.05 \mathrm{ml}$ of diluted culture filtrates were transferred to wells and incubated for 4 days at $36^{\circ} \mathrm{C}$ in $\mathrm{CO}_{2}$ incubator. Cytopathic effect was examined daily for rounded and shriveled cells and detachment). Dilute TSB 1:5 in DPBS was used as control [23].

\section{Results}

\section{Foodborne outbreak description}

At night of September 13, 2005, a 13-years-old boy was hospitalized in the Pediatric Medical Center of Barra da Tijuca, Rio de Janeiro (RJ), resulting in the notification of the case. Medical reports demonstrated intense abdominal pain and severe diarrhea. Computerized tomography and ultra-sound revealed mesenteric adenitis. Clinical symptoms evolved to bloody diarrhea, cramps and one emetic episode. Intravenous antibiotic treatment was used each 12 hours (Rocefin, Roche). At September 16, 2005, the patient returned to home. Coproculture revealed a sorbitol-negative, indole positive, non-motile E. coli. The strain agglutinated $\mathrm{O} 157$ antiserum, being identified as E. coli $\mathrm{O} 157: \mathrm{H}^{-}$

The victim declared that the week before the burden of symptoms, had lunch and consumed different meals at the canteen of school where he studied, at the city of Jacarepagua, RJ. The canteen was served by an outsourced catering service. At home, the meals were composed mainly by red meat, fruits and vegetables, purchased in three commercial food establishments. The day before the beginning of symptoms, the teenager and his family had lunch at the restaurant of the residential condominium where they lived, at Barra da Tijuca, RJ. The dairy routine of victim was going to school, play with friends at residential condominium, play football and swim in the swimming pool. The family did not get sick even eating the same foods and meals of teenager, at the same restaurant and at home, except at school canteen.

Five days before get sick, the victim traveled to Tiradentes city, State of Minas Gerais (from 08 to 10/09/2005), in a travel organized by school. He had several meals at different restaurants of diverse cities, eating barbecue (including rare bovine meat), pizza, snacks, 
lettuce, pepper, homemade ice cream and water from a font in a touristic city. Teachers and other students that also were in the tour were interviewed in order to identify possible consumption of foods commonly linked to transmission of E. coli O157 (rare red meat, non-potable water, fruits and vegetables). Among the 62 people that were in the tour, 58 (52 teenagers and 6 six adults) were interviewed. Five teenagers declared gastrointestinal symptoms after travel. One of them reported intense watery diarrhea, low fever, prostration, body pain and abdominal pain during four days. There were no nausea or vomit episodes. The same teenager had sore throat with oropharyngeal hyperemia. During the travel, students have eaten hamburgers, snacks, rare red meat, vegetables, fruits, non-potable water, homemade ice cream and Mina's type cheese.

At September 16, 2005, Sanitary Surveillance Service of the State of Minas Gerais sent a technical note and a sanitary alert informing about the foodborne case notified at Rio de Janeiro and the possible involvement of food establishments where the group had their meals during the travel to Minas Gerais. Official inspections were carried out in the establishments of Minas Gerais, as well. Inspections were done aiming at the verification of GHP and SOP, traceability of raw material and manipulation of suspect foods, as hamburgers and unpasteurized cheeses. Sanitary officers did not found important irregularities inside food establishments, turning the attention to food contamination inside the canteen school at Rio de Janeiro city where teenagers had meals before travel.

Based on this, several foods served at school canteen were sampled and sent to the Reference Laboratory of Public Health of Rio de Janeiro Noel Nutels. A Tomato salad added with Minas type cheese demonstrated inadequate sensorial characteristics and counts of thermo tolerant coli forms above the limit established by Brazilian Microbiological Standard regulation [26]. The sampling was carried out some days after the beginning of victim symptoms and the analysis demonstrated E. coli $\mathrm{O} 157: \mathrm{H}^{-}$, stx gene negative. Based on the results, this food was considered the most probable vehicle of the foodborne disease. Additional sampling of Minas type cheese was carried out at supermarket where the cheese was purchased, but E. coli $\mathrm{O} 157: \mathrm{H}^{-}$was not found. Other sources of contamination also could be tomato used for salad or food handlers, but these were not investigated.

\section{Discussion}

This study describes a foodborne outbreak occurred in Rio de Janeiro, Brazil, with characteristics indicating a foodborne illness caused by E. coli $\mathrm{O} 157: \mathrm{H}^{-}$. The incubation time, victim' symptoms and the isolation of E. coli $\mathrm{O} 157: \mathrm{H}^{-}$from the patient stool and from a tomato salad added of a regional cheese prepared in a food establishment where the victim had made some meals strongly indicated that the foodborne outbreak was caused by E. coli O157: $\mathrm{H}^{\text {. }}$ An interesting fact was that the E. coli $\mathrm{O} 157: \mathrm{H}^{-}$isolated from patient's coproculture was verotoxin-positive, while the strain isolated from the tomato salad did not produce verotoxin in culture tissue assay. Some possible explanations for these results are the lost of stx genes or the incapacity of expression of these genes outside of intestine. For example, Themphachana, et al. [27] have reported a stx-negative $E$. coli $\mathrm{O} 157$ causing 228 cases of diarrhea in Thailand and suggested that the causative agent was originally stx-positive, but lost the gene after establishing infection. Similar results were demonstrated by Whatahiki, et al. [28] who characterized strains of E. coli O111 and $\mathrm{O} 157$ isolated from raw beef dishes responsible for 181 infected patients and five deaths, in Japan. E. coli O157 isolated from stools demonstrated diverse stx gene profiles and molecular analyses indicated that isolates originated from a single clone. The same authors suggested that $E$. coli O111 stx2-positive converted in stxnegative during infection. Recently, Licznerska, et al. [12] reported that the induction of stx genes of some E. coli O157 only happens during human infections, mainly inside intestine, explaining why some strains have the stx genes, but do not produce Shiga-toxin during in vitro tests.

Based on epidemiological investigation and laboratorial results, Sanitary Surveillance Service of Rio de Janeiro assumed that the foodborne outbreak was caused by E. coli O157: $\mathrm{H}^{-}$. In order to avoid new illness cases, officers carried out new inspections in the food establishments where the victim used to buy foods, i.e. restaurant of the residential condominium where teenager lives, his school and supermarkets next to his home. Further, in the school, a discussion session was done with students, focusing on clinical symptoms and most probable ways of contamination of E. coli O157. Guideline information about food consumption in trips was sent to school, as well.

In Brazil, E. coli $\mathrm{O} 157$ is not routinely investigated by reference laboratories, because this food pathogen is not frequently found on foods or causing reported illnesses. However, there is the possibility of occurrence of non-notified cases caused by this microorganism. The lack of reported cases in Brazil can be reflect of the low prevalence of $E$. coli $\mathrm{O} 157$ on foods $[29,30]$ or because this microorganism has not been investigated routinely by food microbiology laboratories, making difficult to know the true incidence of E. coli O157 in Brazil.

Even though information about E. coli $\mathrm{O} 157$ is not abundant in Brazil, the importance of this food pathogen is well recognized and based on this fact Brazil has started to implement monitoring programs and control measures in order to prevent E. coli $\mathrm{O} 157$ illnesses. For example, the Ministry of Agriculture, Livestock and Food Supply published in 17, July 2015, the regulation DIPOA/SDA 01 , approving sampling and analytical procedures for investigation of verotoxigenic E. coli (serovars O26, 045, O103, O111, O121, $\mathrm{O} 145$ and O157) in raw beef products. This regulation will increase database about real prevalence of enteropatogenic E. coli serovars and will contribute to food safety of Brazilian food products.

\section{Conclusion}

The present study reported the first foodborne disease human case caused by E. coli $\mathrm{O} 157: \mathrm{H}^{-}$case in Brazil. The isolation of the same microorganism in a tomato salad added with Minas type cheese prepared in the same local where the victim had lunch some days before the burden of symptoms, strongly indicated that the source of contamination was the canteen of school where the victim studied.

\section{References}

1. Bodouei MA, Morabito S, Najafifar A, Mazendarani E. Molecular characterization of enterohemorrhagic Escherichia coli hemolysin gene (EHEC-hlyA)-harboring isolates from cattle reveals a diverse origin and hybrid diarrheagenic strains. Infection, genetics and evolution. 2016; 39: 342-348.

2. Majowicz S, Scallan E, Jones-Bitton A, Saggent J, Stapleton J, Angulo F. 
Global Incidence of Human Shiga Toxin-Producing Escherichia coli Infections and Deaths: A Systematic Review and Knowledge Synthesis. Foodborne Pathog Dis. 2014; 11: 477-485.

3. Khalil, RK, Frank, JF. Behavior of Escherichia coli O157:H7 on Damaged Leaves of Spinach, Lettuce, Cilandro and Parsley Stored at Abusive Temperatures. J Food Prot. 2010; 73: 212-220.

4. Caprioli A, Morabito S, Brugere H, Oswald E. 2005. Enterohaemorrhagic Escherichia coli: emerging issues on virulence and modes of transmission. Vet Res. 2005; 36: 289-311.

5. Rangel J, Sparling P, Crowe C, Griffin P, Swerdlow D. Epidemiology of Escherichia coli O157:H7 Outbreaks, United States, 1982-2002. Emerging and Infection Diseases. 2005; 11.

6. Gould LH, Mody RK, Ong KL, Clogher P, Cronquist AB, Garman KN, et al. Increased recognition of non-O157 Shiga toxin-producing Escherichia col infections in the United States during 2000-2010: Epidemiologic features and comparison with E. coli O157 infections. Foodborne Pathogens and Disease. 2013; 10: 453-460

7. Fields PI, Blom K, Hughes $\mathrm{HJ}$, Helsel LO, Feng $\mathrm{P}$, Swaminathan $\mathrm{B}$ Molecular Characterization of the Gene Encoding $\mathrm{H}$ Antigen in Escherichia coli and Development of a PCR-Restriction Fragment Length Polymorphism Test for Identification of E. coli O157:H7 and O157:NM. Journal of Clinical Microbiology. 1997; 1066-1070.

8. Allerberger F, Dierich MP, Gruber-Moesenbacher U, Liesegang A, Prager R Hartmann G, et al. Nontoxigenic sorbitol-fermenting Escherichia coli O157: $\mathrm{H}^{-}$ associated with a family outbreak of diarrhea. Wien Klin Wochenschr. 2000; 112: 846-850.

9. Karch H, Bielaszewska M. Sorbitol-Fermenting Shiga Toxin Producing Escherichia coli O157: $\mathrm{H}^{-}$Strains: Epidemiology, Phenotypic and Molecula Characteristics and Microbiological Diagnosis. J Clin Microbiol. 2001; 39 2043-2049.

10. Ammon A, Petersen LP, Karch H. A large outbreak of hemolytic uremic syndrome caused by an unusual sorbitol-fermenting strain of $E$. coli $O 157: \mathrm{H}^{-}$. J Infect Dis. 1999; 179: 1274-1277.

11. Schmidt H, Scheef J, Huppertz HI, Frosch M, Karch H. Escherichia coli O157: $\mathrm{H} 7$ and $\mathrm{O} 157: \mathrm{H}^{-}$strains that do not produce Shiga toxin: phenotypic and genetic characterization of isolates associated with diarrhea and hemolyticuremic syndrome. J Clin Microbiol. 1999; 37: 3491-3496.

12. Licznerska K, Falenczyk BN, Bloch S, Dydecka A, Topka G, Gdsior T, et al. Oxidative Stress in Shiga Toxin Production by Enterohemorrhagic Escherichia coli. Oxid Med Cell Longev. 2016; 1-8.

13. Bielaszewska M, Schmidt $H$, Liesegang A, Prager R, Rabsch W, Tschape $H$, et al. Cattle can be a reservoir of sorbitol-fermenting shiga-toxin-producing Escherichia coli O157: $\mathrm{H}$-strains and a source of human diseases. J Clin Microbiol. 2000; 38: 3470-3473.

14. Nielsen S, Frank C, Fruth A, Spode A, Prager R, Graff A, et al. Desperately seeking diarrhoea: outbreak of haemolytic uraemic syndrome caused by emerging sorbitol-fermenting shiga toxin-producing Escherichia coli $0157: \mathrm{H}-$ Germany. 2009. Zoonoses Public Health. 2011; 58: 567-572.

15. Brandal LT, Lobersli I, Stavnes TI, Wester Al, Lindstedt BA. First Report of the Shiga Toxin 1 Gene in Sorbitol-Fermenting Escherichia coli O157:H-. J Clin Microbiol. 2012: 50: 1825-1826
16. Sallam Ki, Mohammed MA, Ahdy AM, Tamura T. Prevalence, genetic characterization and virulence genes of sorbitol-fermenting Escherichia col O157:H-and Escherichia coli O157:H7 isolated from retail beef. Int J Food Microbiol. 2013; 165: 295-301.

17. Cerqueira AM, Guth BE, Joaquim RM, Andrade Jr. High occurrence of Shiga toxin-producing Escherichia coli (STEC) in healthy cattle in Rio de Janeiro State, Brazil. Vet Microbiol. 1999; 70: 111-121.

18. Irino K, Kato Ma, Vaz Tm, Ramos II, Souza Ma, Cruz AS. Serotypes and virulence markers of Shiga toxin producing Escherichia coli (STEC) isolated from dairy cattle in Sao Paulo State, Brazil. Vet icrobiol. 2005; 105: 29-36.

19. Paula CMD, Casarin LS, Tondo EC. Escherichia coli O157:H7-patogeno alimentar emergente. Vig Sanit Debate. 2014; 2: 23-33.

20. Loiko MR, Paula CMD, Langone ACJ, Rodrigues RQ, Cibulski S, Rodrigues $\mathrm{RO}$, et al. Genotypic and antimicrobial characterization of pathogenic bacteria at different stages of cattle slaughtering in southern Brazil. Meat Science. 2016; 116: 193-200.

21. Centro De Vigilancia Epidemiologica. Casos confirmados e coeficientes de incidencia de casos autoctones de doencas de notificacao compulsoria no estado de Sao Paulo, no periodo de 1998 a 2008. 2013.

22. OPAS/WHO. Procedimientos para la Investigacion de Enfermedades transmitidas por alimentos. Manual de la International Association of Milk Food and Environmental Sanitarias Inc. Publicacion Cientifica $N^{\circ} 367.2^{\text {nd }}$ edn. 1978.

23. FDA/CFSAN. Isolation Methods for Enterohemorrhagic E. coli O157:H7. In Bacteriological Analytical Manual. Food and Drug Administration, Centers for Food Safety and Applied Nutrition. 2001.

24. Ewing WH. Edwards and Ewing's Identification of Enterobacferiaceae, $4^{\text {th }}$ edn. Elsevier Science Publishing Co., Inc., New York. 1986; 536.

25. Orskov F, Orskov I. Serotyping of Escherichia Coli. Methods on Microbiology 1984; 14: 43-112.

26. Brasil. Agencia Nacional de Vigilancia Sanitaria. Resolucao RDC $n^{\circ} 12$ de 02 de janeiro de 2001. Aprova o Regulamento Tecnico sobre Padroes Microbiologicos para Alimentos. Diario Oficial da Republica Federativa do Brasil, Brasilia, Janeiro de. 2001.

27. Themphachana M, Nakaguchi $Y$, Nishibuchi $M$, Seto K, Rattanachuay $P$ Singkhamanan $\mathrm{K}$, et al. First report in Thailand of a stx-negative Escherichia coli 0157 strain from a patient with diarrhea. Southeast Asian Journal of Tropical Medicine and Public Health. 2014; 45: 881-889.

28. Watahiki M, Isobe J, Kimata K, Shima T, Kanat J, Shimizu M, et al Characterization of enterohemorragic Escherichia coli $\mathrm{O} 111$ and $\mathrm{O} 157$ strains isolated from outbreak patients in Japan. J Clin Microbiol. 2014; 52: 2757-2763

29. Rodrigues R, Loiko M, Paula CMD, Hessel CT, Jacxsens L, Uyttendaele $\mathrm{M}$, et al. Microbiological contamination linked to implementation of good agricultural practices in the production of organic lettuce in Southern Brazil. Food Control. 2014

30. Ceuppens S, Hessel CT, Rodrigues RQ, Bartz S, Tondo Ec, Uyttendaele M. Microbiological quality and safety assessment of lettuce production in Brazil. Int JI Food Microbiol. 2104; 181: 67-76.
Austin J Nutri Food Sci - Volume 5 Issue 1 - 2017 ISSN : 2381-8980 | www.austinpublishinggroup.com Tondo et al. (C) All rights are reserved
Citation: Santos RFC, Nascimento JDS, Geimba MP, Hessel CT and Tondo EC. First Report of Human Gastroenteritis Caused by Escherichia Coli O157:H'. Austin J Nutri Food Sci. 2017; 5(1): 1083. 